\title{
Fostering Scientific and Numerate Practices in Journalism to Support Rapid Public Learning
}

Louise Yarnall

SRI International, louise.yarnall@sri.com

Michael Andrew Ranney

University of California, Berkeley, ranney@berkeley.edu

Follow this and additional works at: https://digitalcommons.usf.edu/numeracy

Part of the Journalism Studies Commons

\section{Recommended Citation}

Yarnall, Louise, and Michael A. Ranney. "Fostering Scientific and Numerate Practices in Journalism to Support Rapid Public Learning." Numeracy 10, Iss. 1 (2017): Article 3. DOI: http://dx.doi.org/10.5038/ 1936-4660.10.1.3 


\title{
Fostering Scientific and Numerate Practices in Journalism to Support Rapid Public Learning
}

\begin{abstract}
Journalism has the potential--and arguably the mandate--to expand public understanding of societally important phenomena. However, some methods for more effectively educating the public have been persistently underutilized: in particular, embedding informative numerical rates and efficient scientific explanations in news reports. In the current era of disrupting and downsizing the news business, the challenges to using such methods have only increased. To address this problem, this article seeks to (a) raise awareness about the psychological reasons that help explain why it is crucial to use such elements in news reports, and (b) exhibit some methods for doing so that require modest effort. Building on a review of relevant psychological literatures, principles, and existing reporting methods, we describe findings from a series of cognitive-scientific studies that demonstrate how using key--and relatively minimal--scientific and numerical elements can enhance public learning from news reports. We conclude by also describing curricula and resources designed to help journalists and bloggers use these methods.
\end{abstract}

\section{Keywords}

journalism

\section{Creative Commons License}

\section{(c) (1) (9)}

This work is licensed under a Creative Commons Attribution-Noncommercial 4.0 License

\section{Cover Page Footnote}

Louise Yarnall, an education researcher, is a Senior Social Science Researcher at SRI International, Menlo Park, CA; she specializes in STEM workforce training and assessment design, adult learning and motivation, and designing innovative technologies for lifelong learning. Formerly, she worked for 10 years as a daily newspaper reporter in Los Angeles. She holds a Ph.D. from the University of California, Los Angeles.

Michael Andrew Ranney, an experimental cognitive psychologist, is a Professor in the Graduate School of Education at the University of California, Berkeley (UCB); he also serves almost ten other UCB faculties, including Psychology, Cognitive Science, and the Institute of Personality and Social Research. 


\section{Introduction}

When journalists communicate, they have an opportunity to put the news into perspective and educate media audiences by including critical numbers and key scientific ideas in their stories. The reasons why they do not use such elements more consistently are not well understood, but the lack of such consistency has been attributed to a combination of: time pressure, habit, news values, accepted practices for succinct communication, inaccurate preconceptions, lack of self-confidence (e.g., the fear of "getting a statistic wrong"), and limited fluency in scientific and numerical reasoning (Curtin and Maier 2001; Meyer 2002; Boykoff and Boykoff 2007; Cohn and Cope 2012; Paulos 2013; Harrison 2016).

Over the years, both critique and practical advice have been offered to improve journalistic uses of scientific and numerical information. In this article, we review and build on this advice by summarizing research that provides the psychological and cognitive scientific basis for using such practices in journalism. In doing so, we also provide practical advice that is applicable and actionable in the current era of news production, which is typified by the decline of newsroom organizations, the proliferation of new media platforms and independent bloggers, and increased competition from social media. The need to emphasize factual information is increasing, and better methods for doing so are needed, particularly with the rise of "fake news" (Silverman 2016; Timberg 2016). (Indeed, it can be argued that the results of many of the 2016 U.S. elections - presidential, congressional, state, and local-were influenced by the differential abilities of subgroups to determine which pieces of information were hoaxes and which were not.)

We first (a) review foundational psychological theory that explains the conditions under which media can transform public understanding of news and issues, and (b) describe the range of ways that journalists may use scientific and numerical information in their stories. Following this introduction, we assess the barriers to implementing such scientific and numerical practices in the current news production economy. Then we review a series of cognitive scientific studies that demonstrate how using key - and relatively minimal — scientific and numerical reporting practices can enhance public learning. We conclude by describing both curricula and resources designed to help journalists, new media reporters, or bloggers identify and estimate benchmark rates for common, socially important phenomena. By "phenomena," we refer to the wide range of social and physical entities and activities that may be characterized descriptively in the news, and we will provide illustrative examples of such phenomena. We believe that magnitude and causality are key elements that advance public understanding of phenomena in the news. Magnitude helps gauge the relevant social impacts of events and helps track their ongoing status - through rates of growth and changing distributions 
among the population; causal explanations help to mitigate risks and prepare for the future.

\section{Psychological Studies Illustrating Mass Media Impacts on Audiences}

Philosopher Alain de Botton has observed that the news has greater influence over adult learning than any academic institution: "Once our formal education has finished, the news is the teacher" (De Botton 2014, 5). In mass communications research, this influence has been studied through two theories: (a) agenda-setting theory, which focuses on how more frequent coverage of an issue raises public awareness about particular topics (McCombs and Shaw 1972), and (b) framing theory, which discusses how the language and descriptive techniques that journalists employ (metaphors, jargon, symbols, etc.) convey how media consumers should value or think about an issue (Fairhurst and Sarr 1996; Scheufele 1999).

However, psychologists have found that journalism's impact on the public's understanding of issues is not straightforward, but rather negotiated by a media consumer's cognitive biases. For example, individual media consumers often filter media information for confirmation of their beliefs (for an overview, see Scheufele and Scheufele 2010). Or, media consumers may overestimate the chance of personal gain when a news story emphasizes the positive aspects of a news event or, conversely may overestimate the chance of personal loss when a news story emphasizes negative aspects of an event (Kahneman and Tversky 1984). Similarly, journalists approach news stories with their own interpretive strategies; in particular, they select and emphasize three elements in reporting the news: conflict, human interest, and potential societal consequences (for a review, see Price, Tewksburty, and Powers 1997, and for other related norms, see Boykoff and Boykoff 2007). As a result, both media consumers and journalists may be paying less attention to information that contradicts their own beliefs, understanding, personal interests, or professional priorities. Such biases are sub-optimal for informing citizens about phenomena of importance in their lives.

Despite such filters, the media sway public opinion effectively under certain conditions. For example, if media consumers (and, presumably, journalists) actually know very little about an issue, they are more likely to be open to the media's guiding influence. This is called the establishing effect of the media. Additionally, when multiple news media organizations cover an issue over a sustained period of time, the key elements of the issue become more available in the memory of both media audiences and journalists (McCombs and Shaw 1972; McCombs 2005; McCombs and Shaw 1993), making it more likely that the vast majority will take those elements into account in judging related matters (Hastie 
and Park 1986; Iyengar and Kinder 2010). This is called the transformation effect. For example, the more the news media report on officer-involved shootings of African-Americans, the more media consumers develop a perspective that this situation is a phenomenon of interest. (See Karabel 2015, for an analysis of the transformation effect of this particular news story.) Through either the establishing effect or the transformation effect, media can change what psychologists call a person's schema - that is, an organizing framework - for interpreting breaking news, public policies, situations, or candidates.

While it is taken for granted that journalists frame the public's view of events through brief encapsulations, such as iconic images and headlines, ${ }^{1}$ eyetracking studies provide rather fine-grained empirical evidence of how media consumers filter and process news each day. Such studies use sensors to track the eye positionings of media consumers as they gaze at a Web page or printed news page, and then use correlational analyses to link eye lingerings with finely specific sections of text. These studies distinguish between eye pauses

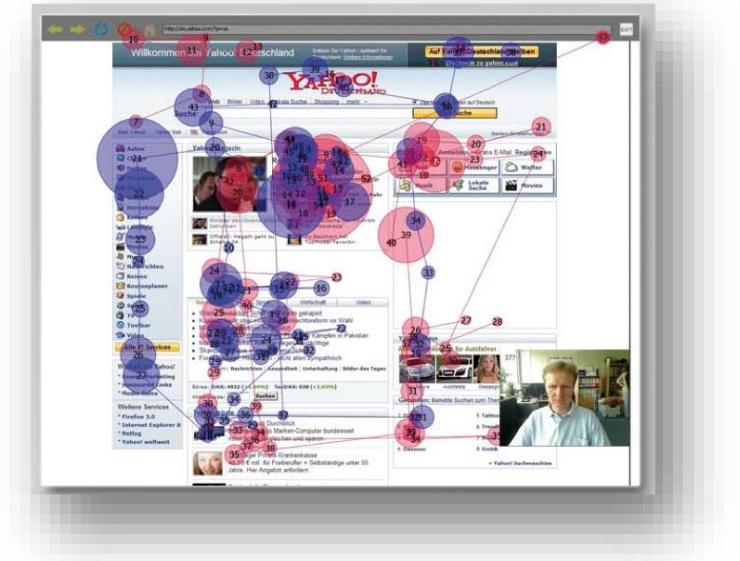

Figure 1. Example media eye-tracking scanpath over screen/text elements. Used under Creative Commons License from SMI Eye Tracking Solutions Blog (http://www.eyetracking.co.kr/58).

(fixations), indicating focused attention, and movements to another position on the page (saccades), indicating shifts in attention. The resulting series of fixations and saccades is called a scanpath, which typically looks like brightly colored scribbles on a page, with larger bubbles located where longer fixations occur (see Fig. 1). To further understand what media consumers are thinking as they fix and shift their gaze across the page, researchers often interview study participants about their thoughts as they peruse media information.

Based on such scanpath analyses, research shows that media consumers engage initially in an orientation phase that involves selecting a subset of stories for further

\footnotetext{
${ }^{1}$ The frame is also conveyed in what journalists call the lede, typically the first paragraph of a news story that includes the who, what, where, when, and why. (The lede is a bit like an abstract in a journal article.) It is also conveyed in broadcast media through the teaser, which is the headline that appears at the side or bottom of a TV screen or that a broadcaster presents at the outset of a full broadcast listing the upcoming news reports. Finally, it is conveyed through the sound bite, which refers to a succinct quotation of some newsmaker or news participant that captures the framing of a given situation in a few pithy words.
} 
attention and then an informational phase that focuses attention on selected stories (Quinn 2012). Once the informational phase begins, media consumers allocate a minute, on average, to processing each selected story.

This brief overview of the psychological and scanpath literature indicates that media effects on audience learning are constrained by cognitive filtering and limited processing time. However, media learning impacts are most likely to occur when an issue is novel to the audience and when media coverage over time focuses on a consistent, repetitive, set of informational elements.

\section{How Journalists Produce News}

Most literate adults have learned, implicitly, that news stories report the five W's: Who, What, Where, When, and Why-yet this understanding of story structure does not translate into a comprehensive understanding of the news production context. Outside of a brief period of sociological study of journalism newsrooms in the late 1970s by Herbert Gans, little research exists regarding actual news production contexts (Klinenberg 2005). To better understand the challenges of providing numerical and scientific details, it is helpful for numeracy advocates to consider the following summary of the context of how news stories get produced.

Studies of the journalistic newsroom culture and communications methods show the myriad decisions that go into the production of each story. We do not review all these media production processes exhaustively here, but focus instead on how they may pose challenges to the inclusion of scientific and numerical content in news stories.

At the top of any news organization are the news executives, who allocate resources for the entire enterprise. Those resources typically come from two sources: subscriptions and advertising. As is by now well known, both income sources have declined for most news media organizations as audiences have migrated to online search and social media platforms for information. Yet even in this turbulent ("disrupted") business context, news media organizations such as The Associated Press wire service and its contributing print-news organizations still produce most of the original news reporting and writing consumed by most citizens (Pew Research Center 2016).

News organizations were historically family-owned, but beginning in the 1970s, media organizations embarked on three phases of restructuring, which have been characterized as: (1) taking companies out of private hands, (2) raising capital with public stock offerings, and (3) reforming the mission to meet stockholders' bottom-line demands (Klinenberg 2005). During that time, news executives have been tasked with reducing labor costs through layoffs, streamlining production processes, investing in digital technologies, and merging different media providers and distributors. 
Even in the current era of newsroom cutbacks, professional news organizations run in a hierarchical fashion. In the newsroom, the news editors make the ultimate determinations about the topics to be covered and the prominence that particular stories will have in the final news product. Reporters-whether on staff or freelancing bloggers - gather the news as dictated by editorial policy, primarily through email or telephone interviews with individual sources, observations of meetings, analyses of a variety of public records, and reviews of official press releases and media reports.

Before the rise of the Internet, both television and newspapers produced local stories roughly every 24 hours, while the wire services (e.g., The Associated Press, United Press International, Reuters) gathered, edited, and reported some news stories on a constant basis, serving as an electronic distribution system to share stories among their member news organizations. With the Internet, reporting for nearly all organizations takes place on a rolling basis - from the initial "tweet" on Twitter of a reporter's observation of the breaking news to the brief report that appears on the news company's 24-hour Internet news feed to the fuller report that follows in the print or broadcast form. Reporters and editors are making decisions about what to report from the moment that a news-making event occurs. They base these decisions on judgments about how best to address the demands of public interest, competition from other media organizations, and the capacity to accurately and reliably characterize an emerging situation.

In addition to the recent increases in time pressure and resource cutbacks, news production staff members face increased pressure to represent events in multimedia formats. Before the Internet and the compression of newsroom budgets, there were various segments of responsibility in news production: reporters gathered the news and wrote the first drafts (usually newspaper reporters, whose work was then shared via the wire services with television and radio reporters), photographers shot and edited photographs, copy editors cleaned the print reporters' copy of grammatical errors, misspellings, and/or possible factual inaccuracies, and various levels of news editors (city editor, managing editor, editor-in-chief) determined headlines and how to position the stories in the final televised or print product.

Today, while a top tier of reporters continues to get time to compose thoughtful, analytical stories on a 24-hour or longer cycle, a growing second tier of reporters (i.e., the "digital staff") is charged not only with reporting and writing constantly, but also photographing or video recording stories, uploading them into a presentation system, laying them out, writing their own headlines, and - with the layoffs in the ranks of copy editors-editing them. As a result of such rising emphasis on technological production and compressed production and time resources, priorities are shifting in newsrooms about what to cover and how deeply. Judging by reports disseminated over the past decade by The Poynter Institute and Pew Research Center for Journalism \& Media, traditional newsrooms have 
generally reduced budgets for longer-term investigative reporting activities, which represent one of the typical kinds of newsroom assignments that lead to deeper levels of information. One U.S. study of the local television news (Just, Levine, and Regan 2002) noted that the ratio of investigative-to-routine news stories had steadily declined over the preceding five years from 1-in-60 to 1-in-150. Further, routine "beat" reporting in all newsrooms - often a fruitful context for generating deeper understanding of societal trends and civic processes - has been dramatically reduced. Rather than sending reporters out to most public meetings and events, news organizations have created conditions that force reporters to rely on secondhand information from the Web, with predictably problematic results. ${ }^{2}$ These shifts mean that reporters are working with less guidance from editors (because there are fewer of them) and supportive external sources on the beat, and relying increasingly on secondary Web-based information sources. In practice, this means that journalists learn about their work differently. Where once they learned through informal, on-the-job contacts cultivated through the newsroom culture, beat reporting, and investigations, they are increasingly expected to work in isolation, relying on secondary Web-based resources and archives.

Further, the pressure to "do more with less" in journalism is unlikely to change. From 1990 to 2009, 14\% of newspapers closed, paid circulation declined by 30\%, and daily advertising revenue declined by 23\% (Pew Research Center 2012). Paradoxically, enrollment in journalism undergraduate programs grew $44 \%$ during the same time frame-although that tide appears to have turned. By 2013, undergraduate enrollment in journalism and mass communications was in its third straight year of decline, particularly at the Master's degree level (Becker, Vlad, and Simpson 2014).

\section{The Call for Scientific and Numerate Practices in Journalism}

Even in the latter part of the 20th century, when corporate mergers had already taken hold in the news industry, there was already concern that journalists were not using appropriate practices to ensure objectivity and independence. As a corrective measure, two critics, Philip Meyer, a journalist and journalism professor, and John Allen Paulos, a mathematics professor, advocated for more scientific and numerical skill in reporting. The core ideas from their work provide an overview of the key elements of such practices.

\footnotetext{
${ }^{2}$ As traditional newsrooms have reduced investigative resources, investigative work has shifted to nonprofit outlets:

http://www.salon.com/2014/08/31/why were living in the golden age of investigative journal $\underline{\mathrm{ism} /}$ (accessed Dec 16, 2016)
} 
Meyer, who particularly advocated scientific methods, is viewed as a pioneer in showing journalists how to use both polls and computer databases in reporting. A sample of the scientific principles he recommends in his seminal book, Precision Journalism (2002), is illustrated in Table 1.

Table 1. A Sample of Meyer's Scientific Principles for Reporting the News

\begin{tabular}{|c|c|c|}
\hline Scientific Concept & Definition of Principle & Meyer's Journalistic Application \\
\hline Theory-based inquiry & $\begin{array}{l}\text { A theory is a rationale for making } \\
\text { hypotheses. These hypotheses may be tested } \\
\text { to determine if they are true or false. }\end{array}$ & $\begin{array}{l}\text { Reporters, like scientists, are "in the } \\
\text { business of reality testing." Although } \\
\text { editorial writers blamed the Watts riots in } \\
\text { the } 1960 \text { s on the lack of opportunity for } \\
\text { advancement of the rioters, the Detroit } \\
\text { Free Press disconfirmed an aspect of this } \\
\text { theory when it found that people who } \\
\text { attended college were just as likely to } \\
\text { participate in the riot as high school } \\
\text { dropouts. }\end{array}$ \\
\hline $\begin{array}{l}\text { Categorical data vs. } \\
\text { continuous data }\end{array}$ & $\begin{array}{l}\text { Continuous data are organized in a scale } \\
\text { where each incremental unit is equivalent. } \\
\text { Categorical data are sorted into classes } \\
\text { based on a characteristic. }\end{array}$ & $\begin{array}{l}\text { Reporting annual income reflects a } \\
\text { continuous data scale; but an income } \\
\text { range in a poll reflects categorical data. }\end{array}$ \\
\hline Probability sampling & $\begin{array}{l}\text { The discipline of statistics shows us how } \\
\text { modestly-sized samples can yield precise } \\
\text { estimates of population parameters. We can } \\
\text { also calculate the precision of the estimate } \\
\text { by computing the degree of error. }\end{array}$ & $\begin{array}{l}\text { Meyer describes how to develop a random } \\
\text { sample of names and numbers for polling } \\
\text { purposes from a local phonebook, and he } \\
\text { describes how to query those who answer } \\
\text { the phone to assure the sample is } \\
\text { representative by age, race, or education. }\end{array}$ \\
\hline Quasi-Experimental design & $\begin{array}{l}\text { To make a causal inference, the hypothesis } \\
\text { should be tested with a sample exposed to } \\
\text { the hypothetical treatment condition and a } \\
\text { comparison sample not exposed to that } \\
\text { condition. }\end{array}$ & $\begin{array}{l}\text { To test the impacts on illegal underage } \\
\text { beer sales of police crackdowns in one } \\
\text { North Carolina town, Meyer's journalism } \\
\text { students asked equal samples of } 18 \text {-year- } \\
\text { olds in two different towns to buy alcohol } \\
\text { and report on whether they were checked } \\
\text { for IDs. Rates were significantly higher in } \\
\text { the town with the police crackdowns on } \\
\text { weekends, but not weekdays. }\end{array}$ \\
\hline
\end{tabular}

Paulos (2013) focused on numeracy. In his book, A Mathematician Reads the Newspaper, he collected a series of news stories from diverse fields - national politics and economics, business and social trends, celebrity news, medicine, science, nutrition, sports, and religion - and offered mathematical alternatives to reporting them. Key numerate approaches he recommends are listed in Table 2.

\footnotetext{
${ }^{3}$ In his book, Meyer also discusses mathematical analysis. He offers several applications of mathematically-based game theory as a way to generate ideas for news stories. He also walks his readers through the fundamentals of computing the following useful statistics: rates, percentage differences, fits of statistical models, and adjustments for inflation or population growth over time.

${ }^{4}$ We note that that while the young people were sampled randomly, the two towns were not randomly assigned to the crackdowns, and so it is not a true experiment. There still could be other explanations for why the town with the police crackdowns had higher rates of checking IDs on the weekends, such as the vendors in that town were less willing to sell to underage youth and more welcoming of police crackdowns.
} 
Table 2. A Sample of Paulos' Mathematical Principles for Reporting the News

\begin{tabular}{|c|c|c|}
\hline $\begin{array}{l}\text { Mathematical } \\
\text { Concept }\end{array}$ & Definition of Principle & Paulos' Journalistic Application \\
\hline Probability & $\begin{array}{l}\text { On a scale of } 0 \text { to } 1 \text {, the likelihood of } \\
\text { something to occur. It is computed by } \\
\text { dividing the favorable cases by the total } \\
\text { number of possible cases. The probability } \\
\text { of several independent events all occurring } \\
\text { is the product of all the events' respective } \\
\text { probabilities. }\end{array}$ & $\begin{array}{l}\text { In practice, Paulos notes that an emerging situation is } \\
\text { often dependent on chance rather than the intention of } \\
\text { an individual (e.g..., the president of the United States) } \\
\text { or an institution. }\end{array}$ \\
\hline $\begin{array}{l}\text { Conditional } \\
\text { probability }\end{array}$ & $\begin{array}{l}\text { The probability of an event (A), given that } \\
\text { another event (B), has already occurred. }\end{array}$ & $\begin{array}{l}\text { When covering crime, Paulos counsels journalists to } \\
\text { remember that the relevant conditional probability can } \\
\text { vary according to the relationships of the variables } \\
\text { involved. (For instance, the Prosecutor's Fallacy occurs } \\
\text { when a prosecutor errs by conflating } \\
P(\text { Innocence|Evidence) with } P \text { (Evidence|Innocence) } \\
\text { when the odds of Innocence are much greater than } 1 .)\end{array}$ \\
\hline Frequency & $\begin{array}{l}\text { The rate at which something occurs or is } \\
\text { repeated over a particular period of time or } \\
\text { in a given sample. }\end{array}$ & $\begin{array}{l}\text { Paulos notes that certain sources, such as government } \\
\text { sources, provide more of the news than others. } \\
\text { Therefore, the stories are skewed toward the } \\
\text { government elites that provide much of the news. }\end{array}$ \\
\hline Benchmarks & $\begin{array}{l}\text { A standard or point of reference against } \\
\text { which things may be compared or } \\
\text { assessed. Useful for putting information } \\
\text { into perspective. }\end{array}$ & $\begin{array}{l}\text { Paulos asks journalists to provide not only the cost of a } \\
\text { single budget item in a city government budget, but also } \\
\text { the amount of the total city budget to put the budget } \\
\text { item in perspective. }\end{array}$ \\
\hline Correlation & $\begin{array}{l}\text { A quantity measuring the extent of } \\
\text { apparent relationship(s) among different } \\
\text { variable quantities. }\end{array}$ & $\begin{array}{l}\text { Paulos note that news sources will often collapse a } \\
\text { multifaceted concept along a linear scale. It is important } \\
\text { to remember that information will be lost. Consider the } \\
\text { other dimensions not included in the source's model. }\end{array}$ \\
\hline Causation & Correlation is not causation. & $\begin{array}{l}\text { Paulos cautions against overinterpreting correlations } \\
\text { between two variables. Correlation does not indicate } \\
\text { that one variable causes the other, only that they have } \\
\text { moved in a related manner. A third latent variable could } \\
\text { be the cause. }\end{array}$ \\
\hline $\begin{array}{l}\text { Central Limit } \\
\text { Theorem }\end{array}$ & $\begin{array}{l}\text { The average of many measurements } \\
\text { follows a normal bell-shaped curve even if } \\
\text { the individual measurements do not. }\end{array}$ & $\begin{array}{l}\text { Paulos notes that many quantities on which journalists } \\
\text { report are normally distributed in a population, such as } \\
\text { specific heights and weights, water consumption, raisins } \\
\text { in a cereal box, IQs, hospital admissions in a day, and } \\
\text { soda dispensed by vending machine; therefore, it is } \\
\text { helpful to characterize such normal variations to } \\
\text { provide perspective. }\end{array}$ \\
\hline
\end{tabular}

\section{The Challenges of Greater Journalistic Use of Scientific and Numerate Practices}

Since Meyer and Paulos provided their useful critiques, their work has been used to introduce more scientific and numerate practices into newsrooms. For example, many major news organizations conduct polls, and many routinely incorporate data analysis in investigative journalism. ${ }^{5}$ With the increasing need to report on

\footnotetext{
${ }^{5}$ The 2015 Academy Award-winner for Best Film, Spotlight, which is recognized as one of the few accurate Hollywood portrayals of modern journalistic work, depicts an investigative team from the Boston Globe using the techniques espoused by Meyer and Paulos. They gathered and analyzed data to expose the Catholic archdiocese's practice of covering up and transferring pedophilic priests from one parish to another for two decades.
} 
scientific and health advances, there is wider acknowledgment of the difficulty of crafting such scientific and numerical information. Indeed, one scholar has argued that four types of expert should collaborate around news press releases that regard the topic of infectious disease: subject matter experts to assure accuracy, risk analysts to frame the likelihood of infection, behavioral scientists to explain how to minimize risk, and communication practitioners to explain it clearly (Fischhoff 1993).

However, given the shrinking operating budgets and layoffs in most newsrooms, the need to find ways to efficiently promote the use of scientific and numerate practices has only increased. Further, many journalism education programs still do not emphasize these specific types of analytic skills, preferring instead to focus on production technologies (Yarnall et al. 2008).

In this era, when production and training resources are severely limited, the two core principles of scientific and numerate practice that we have distilled from the work of Paulos and Meyer are as follows:

- When explaining what has occurred, provide numerical information to convey context and support sense-making, such as the rate and scope of a phenomenon.

- When explaining why an event has occurred, identify and summarize the core ideas of relevant scientific explanatory model(s).

In the next section, we review a set of cognitive science studies that examine how providing just these few critical numbers and/or brief explanations can transform understanding.

\section{Educational Impacts of Providing Rates and Scientific Models}

The cognitive research we review has unfolded over the past 16 years. It is based on the theory that providing critical numbers and summaries of scientific models serves to confront tacitly accepted ideas in the minds of media audiences. The view of cognitive science is that we all have such ideas operating in the background of our minds as we take in new information. As can be seen from the media psychology research reviewed earlier in this article, these tacit ideas can often prevent us from learning new information well.

However, we have found through the prior 16 years of experimentation that crisp, germane numbers and apt explanations of causal models can disrupt and correct mistaken audience preconceptions, thus contributing to the educative transformation and establishing effects (as mentioned above) of media. These numbers and explanations are particularly effective when the media consumer is surprised and suddenly made aware of a gap in his/her understanding. The process 
of conceptual change that participants have experienced in our studies contains elements of the following four: (1) Gestalt recentering, which occurs when a detected knowledge gap is productively addressed (Wertheimer 1945); (2) Piagetian accommodation (as opposed to assimilation), which is schematic reorganization triggered by new, discrepant information that fails to conform with expectations (Piaget 1977); (3) analogical productivity/generativity, which is a transformation that occurs when encountering information that is inconsistent, incoherent, or inert with respect to existing analogical models (Holyoak and Thagard 1996); and (4) the instructional principle of advance organization, which involves clarifying informational nuances in advance of receiving new information to improve a learner's capacity to discriminate between their pre-existing knowledge and "surprising" new information (Ausubel and Youssef 1963). In each of these theories, surprising information leads the recipient to engage in some effortful revision of existing knowledge. (See Munnich and Ranney, forthcoming, regarding the utility of surprise.)

To show how this scientific and numerical information surprises and thereby influences media consumers, we first summarize the results of multiple classroomand laboratory-based studies that one of the authors of this article conducted and then we summarize the findings from a pilot study that applied these principles to news articles that included or excluded critical numerical information. We conclude with a description of the journalism resources and curriculum we developed to support journalists in including such numerical and scientific information in their reports.

\section{Classroom and Laboratory Studies}

Ranney and colleagues have conducted a series of classroom and laboratory studies that demonstrate the impacts of providing one or more critical numbers and/or scientific models on how people understand and perceive news and social issues. Those involving numbers are part of the paradigm called "Numerically-Driven Inferencing" (NDI; Ranney et al. 2001; Ranney and Clark, 2016; Ranney et al. 2016). One of the central techniques of the NDI approach is called EPIC, an acronym that refers to a procedure that asks participants to (1) Estimate a quantity regarding a phenomenon, (2) offer a policy Preference about what they would like that quantity to be, (3) receive Information (usually the true base rate of the phenomenon), and then (4) state a new policy preference to see if the participant experienced a Change. NDI projects have addressed each of EPIC's four elements individually and in various configurations (e.g., PEIC, EIC, PIC, and IC, as in Rinne, Ranney, and Lurie 2006).

In some of these studies, the information provided is as simple as a single (or a few) critical numbers. In others, it involved summarizing a basic explanatory scientific model. For example, in experiments regarding global warming and 
climate change, Ranney and colleagues (Ranney et al. 2016; Ranney and Clark, 2016) employed five brief ways to increase acceptance that climate change is both occurring and anthropogenic. In addition to using numerical information, such as providing statistics and graphs about climate change's observed effects, the team also incorporated a 600-word (or shorter) explanatory text summarizing the scientific model of how global warming occurs - or provided links to explanatory videos shorter than 5 minutes in duration. ${ }^{6}$

Engagement in full EPIC interventions per each social phenomenon across these studies typically ranged from 1 to 3 minutes, depending upon how much additional information researchers requested (explanations, attitudes, ratings of surprise to base rates, etc.). The actual information exposure process (i.e., the "I" in EPIC), however, took less time-for instance, from less than 5 seconds for exposure to a correct base rate to about 3 minutes to read a 600-word scientific explanation.

These studies measured policy position change (a kind of learning) by asking participants, before they received information, about the rates of occurrence of particular socially relevant phenomena or about participants' initial degree of agreement with scientific models for a phenomenon (e.g., about climate change in the case just above). For example, participants typically initially underestimated the rate of abortion in society, and their original preferences partially reflected this understanding. However, when they were informed of the true higher-thanexpected rate of abortion, they often (and usually) revised their original policy by setting a higher acceptable base rate for abortion than they had before.

It is important to note that seeing the base rates rarely caused anyone to completely change (i.e., "flip") their position (e.g., from wanting a decrease to wanting an increase), but rather, enabled them to modify their existing policy position to incorporate the actual rates. "Semi-flips" - for instance, from a neutral policy position to a negatively or positively valenced policy position-are more common (Garcia de Osuna, Ranney, and Nelson 2004.) For the purpose of this article, we summarize a few of the study results that focused on providing numerical benchmarks for issues with persistent news value: abortion, police homicides, civilian homicides, and capital punishment.

As can be seen in Table 3, which summarizes some of the NDI change results after exposure to numerical information, a significant percentage of those exposed to the base rates for social phenomena adjusted their positions. The relevant change statistic for those exposed to scientific explanatory models was also noteworthy.

\footnotetext{
${ }^{6}$ Some of these interventions appear on http://www.howglobalwarmingworks.org/ (Ranney and Lamprey 2013), a multi-language Website.
} 
Table 3. Examples of Policy/Preference Changes Following Exposure to Numerical Information via EPIC in Classrooms or Laboratory

\begin{tabular}{|c|c|c|c|c|c|}
\hline Study & $\begin{array}{l}\text { Topics } \\
\text { (n) }\end{array}$ & $\begin{array}{l}\text { Study } \\
\text { Design }\end{array}$ & Rate Metric & $\begin{array}{c}\text { Initial Estimate } \\
\text { Accuracy }\end{array}$ & $\begin{array}{l}\text { Notable Adjustments in } \\
\text { Preference and/or Policy } \\
\text { After Seeing Base Rates }\end{array}$ \\
\hline $\begin{array}{l}\text { Ranney et } \\
\text { al. } 2001\end{array}$ & $\begin{array}{l}\text { Various } \\
\text { topics' rates } \\
(n=93)\end{array}$ & $\begin{array}{l}\text { Pre-Post } \\
\text { change }\end{array}$ & $\begin{array}{l}16 \text { items; topics } \\
\text { included } \\
\text { demographics, } \\
\text { crime, abortion, } \\
\text { immigration, } \\
\text { finances, \& } \\
\text { mobility }\end{array}$ & $\begin{array}{l}8 \text { items were } \\
\text { underestimated, } 6 \\
\text { overestimated, \& } 2 \\
\text { were roughly } \\
\text { accurate; median as } \\
\text { measure }\end{array}$ & $\begin{array}{l}\text { About } 21 \% \text { changed their } \\
\text { preferred numbers on } \\
\text { average; } 2 \text { items yielded } \\
\text { dramatic changes (e.g., legal } \\
\text { immigration and California } \\
\text { population), several yielded } \\
\text { marked changes (e.g., } \\
\text { inflation, U.S. population, and } \\
\text { world population), some more } \\
\text { showed modest changes (e.g., } \\
\text { baccalaureate and home- } \\
\text { ownership rates), and the rest } \\
\text { showed more assimilative } \\
\text { changes (e.g., household } \\
\text { income) }\end{array}$ \\
\hline $\begin{array}{l}\text { Munnich et } \\
\text { al. } 2003\end{array}$ & $\begin{array}{l}\text { Abortion } \\
\text { rates }(n=28) \\
\text { Execution } \\
\text { rate }(n=99)\end{array}$ & $\begin{array}{l}\text { Pre-Post } \\
\text { change }\end{array}$ & $\begin{array}{l}\text { Abortions per } 1 \\
\text { million live births } \\
\text { Executions per } \\
1,000 \text { murders }\end{array}$ & $\begin{array}{l}\text { Abortions per } 1 \\
\text { million live births: } \\
\text { Underestimated } \\
\text { Executions per } 1,000 \\
\text { murders: } \\
\text { Overestimated }\end{array}$ & $\begin{array}{l}65 \% * \S \\
65 \% * \S\end{array}$ \\
\hline $\begin{array}{l}\text { Garcia de } \\
\text { Osuna, } \\
\text { Ranney, } \\
\text { and Nelson } \\
2004\end{array}$ & $\begin{array}{l}\text { Abortion } \\
\text { rates }(n=92)\end{array}$ & $\begin{array}{l}\text { Pre-Post } \\
\text { change }\end{array}$ & $\begin{array}{l}\text { Abortions per } 1 \\
\text { million live births }\end{array}$ & $\begin{array}{l}\text { Abortion rate re } \\
\text { births: } \\
\text { Underestimated }\end{array}$ & $\begin{array}{l}66 \% \text { of status quo participants } \\
\text { changed to prefer a decrease } \\
(44 \%) \text { or an increase }(22 \%) \text { in } \\
\text { abortions }\end{array}$ \\
\hline
\end{tabular}
2004

* Denotes statistical significance $p<.001-.01$

$\S$ The two measures reflect the percentage of those who changed preference among those who offered a non-zero preference. Specifically, of the 23 out of 28 who offered a non-zero preference for abortion, $65 \%$ changed preference, and for the 66 out of 99 who offered a non-zero preference for execution, $65 \%$ changed preference.

Similar results were found in the climate change example. Once study participants were exposed to correct and/or representative scientific information (e.g., numerical or mechanism-based), they consistently decreased their level of denial that humans do not contribute to the current global climate change (Ranney et al. 2016; Ranney and Clark, 2016). To characterize participants' views of climate change, these studies employed a 9-point scale regarding the degree of acceptance of the position that humans are causing global warming (from 1 [no acceptance] to 9 [total acceptance]). After participants were exposed to the numerical and scientific information, these studies found that the average reduction in the denial of human-caused climate change was roughly 30 percent. (Please note that most American citizens already rate their initial global warming acceptance as being higher than the 5.0 midpoint on this scale.) Further, the three studies that assessed the longevities of learning (of the nine total NDI studies reviewed herein) showed that the knowledge and/or attitude changes garnered from these brief EPIC and EPIC-like encounters were satisfactorily long-lasting, as indicated by delayed 
testing administered between one day and 12 weeks later (e.g., Munnich, Ranney, and Bachman 2005; Ranney et al. 2008; Clark and Ranney 2010).

\section{A Study of EPIC Processes in the Context of News Articles}

Such studies raised the question of whether similar policy adjustments can be achieved by embedding such numbers into news reports, more in the manner and context that media consumers would encounter such information. To explore this question, Yarnall and colleagues conducted a pilot study (Yarnall, Ranney, and Johnson 2005) that involved a sample of about 104 students in sections of a Northern California undergraduate journalism course and 15 professional journalists. We asked these students and journalists to engage in an EPIC intervention, with the "I" in EPIC being the inclusion of an extra paragraph in a news story that summarized the critical base rates of a phenomenon reported. Furthermore, unlike the subset of the aforementioned classroom studies that compared how much a study participant's policy position changed before and after exposure to base rate information, this study employed an experimental design that compared the average policy position change among all those randomly assigned to one of two groups: A treatment group exposed to a news article that included the base rates and a control group exposed to a news article that did not include any base rates.

We presented to both treatment and control groups news stories on two different topics, one on abortion and one on police homicide (see Appendix A for the full articles). The abortion story addressed U.S. 2004 presidential candidates' positions on abortion rights. The homicide story focused on a report on an investigation into the killing of a San Francisco police officer in the line of duty. The survey and stories administered to student and journalistic participants were identical in both the treatment and comparison conditions, except that treatment participants received articles that included (near the midpoint of the articles, at the $7^{\text {th }}$ or $8^{\text {th }}$ paragraph) the following additional treatment text that represented the actual occurrence rates per 1 million for abortion and homicide, as follows:

Abortion treatment-article's added text: "Currently, about 340,000 abortions occur for every 1 million live births. This figure reflects actual data from 47 states reporting to the federal Centers for Disease Control plus estimates from California, which does not report such information. California typically accounts for about $23 \%$ of the nation's abortion rates. The remaining two states had relatively small populations."

Homicide treatment-article's added text: "The homicide rate for California police officers is about 80 officers killed for every 1 million people, while the homicide rate for California civilians is 67 killed for every 1 million people, according to figures from the data analysis office of California's state attorney general, Bill Lockyer." 
Not all the invited participants (Treatment $=37$; Control $=82$ ) responded to the full series of follow-up questions about estimated base rates and preferred rates, and so subsamples were analyzed. As may be seen in Table 4, consistent with the classroom NDI studies on the abortion issue, the treatment condition readers shifted their policy preferences about acceptable rates to be closer to the actual base rate of abortion than those not exposed to those numbers. By contrast, although preferences about acceptable rates for police and civilian deaths did not change

Table 4. Abortion Preference Change Results When Exposed (Treatment) or Not Exposed (Control) to News Stories with Base Rates

\begin{tabular}{lcccccccc}
\hline News Issue & $\begin{array}{c}\text { Pretest Median } \\
\text { Estimate of Rate } \\
\text { (Per 1 Million) }\end{array}$ & \multicolumn{2}{l}{$\begin{array}{c}\text { Pretest Median } \\
\text { Preferred Rate } \\
\text { (Per 1 Million) }\end{array}$} & $\begin{array}{c}\text { Posttest Median } \\
\text { Preferred Rate } \\
\text { (Per 1 Million) }\end{array}$ & $\begin{array}{c}\text { \% Participants } \\
\text { Changing Preferred } \\
\text { Rate }\end{array}$ \\
\hline $\begin{array}{l}\text { Condition: } \\
\text { Abortion }\end{array}$ & $\begin{array}{c}\mathrm{T} \\
n=19\end{array}$ & $\begin{array}{c}\mathrm{C} \\
\mathrm{T}=16\end{array}$ & $\mathrm{~T}$ & $\mathrm{C}$ & $\mathrm{T}$ & $\mathrm{C}$ & $\mathrm{T}$ & $\mathrm{C}$ \\
& 10,000 & 15,000 & 5,000 & 27.5 & 100,000 & 27.5 & $63 \%$ & $0 \%$ \\
\hline
\end{tabular}

Treatment response rate $=52 \%$; Control response rate $=20 \%$

among either treatment or comparison participants (as most participants consistently preferred zero homicides), the treatment condition participants shifted their estimates (or recollections) of the actual death rates to be closer to the true rates, as shown in Table 5. Furthermore, when asked to reflect on changes in

Table 5. Police Homicide estimate Change Results When Exposed (Treatment) or Not Exposed (Control) to News Stories with Base Rates

\begin{tabular}{|c|c|c|c|c|c|c|c|c|}
\hline News Issue & \multicolumn{2}{|c|}{$\begin{array}{l}\text { Pretest Median } \\
\text { Estimate of Rate } \\
\text { (Per 1 Million) }\end{array}$} & \multicolumn{2}{|c|}{$\begin{array}{c}\text { Pretest and } \\
\text { Posttest Median } \\
\text { Preferred Rate } \\
\text { (Per 1 Million) } \\
\end{array}$} & \multicolumn{2}{|c|}{$\begin{array}{l}\text { Posttest Median } \\
\text { Estimated or } \\
\text { Recalled Rate } \\
\text { (Per } 1 \text { Million) } \\
\end{array}$} & \multicolumn{2}{|c|}{$\begin{array}{c}\% \text { Participants } \\
\text { Changing Estimated } \\
\text { Rate }\end{array}$} \\
\hline Condition: & $\begin{array}{c}\mathrm{T} \\
n=36\end{array}$ & $\begin{array}{c}\mathrm{C} \\
n=23\end{array}$ & $\mathrm{~T}$ & $\mathrm{C}$ & $\mathrm{T}$ & $\mathrm{C}$ & $\mathrm{T}$ & $\mathrm{C}$ \\
\hline $\begin{array}{l}\text { Police } \\
\text { homicide }\end{array}$ & 100 & 150 & 0 & 0 & 80 & 63 & $75 \%$ & $30 \%$ \\
\hline $\begin{array}{l}\text { Civilian } \\
\text { homicide }\end{array}$ & 1,000 & 150 & 0 & 0 & 70 & 100 & $69 \%$ & $30 \%$ \\
\hline
\end{tabular}

their policy positions, about a quarter of the treatment condition readers of the abortion article and nearly half of the treatment condition readers of the police homicide article cited the numbers in the inserted paragraphs in the treatment articles, sometimes expressing their surprise at these rates, which were either higher (abortion) or lower (police on-duty killings) than they expected. By contrast, those in the comparison condition who changed their policy positions after reading their articles without the rates cited other reasons for their change in perspectives, such as their impressions about the magnitude of the phenomenon as implied by the article, their past knowledge, or a personal belief system; and some noted that they 
had no basis on which to make a judgment since the articles lacked specific rate information.

We also found through this work that, even though various journalistic participants initially protested in surveys about the relevance of such numbers for these phenomena, particularly abortion rates, when they were given such numbers, these journalists behaved as the classroom- and laboratory-study participants: They adjusted their preferences and their understandings of the issue.

\section{A Journalism Curriculum}

Based on the findings from the pilot study, our NDI team developed and piloted a numeracy curriculum for journalism students at UC Berkeley (Ranney et al. 2008). The curriculum was assessed through a (within-subjects and between-subjects) pretest/post-test design, and about half of the students additionally received a delayed post-test 9 weeks after the immediate post-test. The one-week numeracy module included three 90-minute classroom sessions, each packed with numeracy-related activities. In addition, 20 hours of homework were assigned. The highly intensive week focused on eight central types of activity listed below, ordered by the percentages of dedicated class time to each:

- $25 \%$ of class time for (a) estimation practice around a Top 40 list (discussed more below) that summarizes the rates of common social phenomena and (b) estimation strategies such as: disconfirmation attempts (e.g., seeking to invalidate given estimated numbers), benchmarking (e.g., finding a reference quantity relevant to a target quantity), decomposition (e.g., breaking a sought quantity into multiple quantities with better-known rates), coherence-seeking (e.g., increasing phenomenal explanatory clarity/consistency), "whole-pie" contextualizations (e.g., contrasting a quantity with the scope of a more aggregated quantity), and the "Rule of 72" (a heuristic by which one can estimate the time it takes a geometrically increasing phenomenon to double by dividing 72 by the growth rate $)^{7}$

- $20 \%$ for data-foraging tactics, as well as numeracy tips and caveats involving polls, misleading statistics, quantities, and scientific methods;

- $\quad 12 \%$ for exercises about numerical journalism and NDI-based philosophies;

- $12 \%$ for examples of excellent and poor uses of statistics (or the absence of such numbers) in reporting-followed up later by numeracy-focused critiques of the students' own writings;

\footnotetext{
${ }^{7}$ The rule of 72 approximates a natural-logarithm function, such that, for instance, dividing 72 by a growth-rate percentage roughly yields a doubling-period (e.g., with a 3\% annual population growth, a country's populace would double about every 24 years).
} 
- $10 \%$ for modeling the use of numerical and statistical resources;

- $\quad 9 \%$ for students to reflect upon readings (e.g., Huff 1954; Cohen 2001; and parts of Levitt and Dubner 2005), assess their mathematical (largely arithmetic) homework performance, and improve stories involving statistics;

- $6 \%$ for brief discussions of the readings; and

- $6 \%$ for feedback on students' mathematical and writing performances.

As reported by Ranney et al. (2008), the curriculum significantly increased the journalism graduate students' (a) basic mathematical fluency and (b) abilities to estimate quantities they had never estimated before (often by inhibiting or eliminating "wildly incorrect" estimates/calculations, such as "the U.S. uses 1 billion pounds of coal per person per day"). The curriculum even changed students' attitudes about numbers (gratifyingly, largely more positively than negatively) and it changed the students' ability to articulate situations using numbers (Ranney et al. 2008). Finally, $80 \%$ of the journalistic graduate students indicated that they thought future students in their program ought to experience the module, whereas only $9 \%$ thought they should not (with the remaining 11\% supporting use of the module with some alteration; e.g., "If you only change X to be more $\mathrm{Y}$, then it's great.").

\section{Approaches to Creating and Disseminating Targeted Scientific and Numerical Information in the News}

As noted, part of this curriculum for the journalism students included use of a Top 40 list of the rates of common quantifiable phenomena in society. Ranney and his research team (especially with the assistance of Luke Rinne) designed the Top-40 items to include rates associated with demographics, immigration, abortion, personal finance, U.S. economics, crime, health, and the environment. The intention was to provide journalists with quantitative touchstones and benchmarks through which they could understand societally important topics - and to represent fodder through which journalists could generate incisive, informed questions during interviews. (These benchmarks are thus rather like those advocated for in Paulos's aforementioned principles.) Several rounds of culling and editing itemcandidates yielded the final set of 40 items; some desired quantities were (apparently) just not known to humankind or were not available in a form that would make sense in a single number. (For the full list updated to 2015, see pp. 174-177 in Ranney et al. 2016; the public was encouraged to test their awareness 
of these base rates through a quiz at http://morenumerate.org [using pre-2015 numbers, as described in Ranney et al. 2008] $]^{8}$ ).

In the curriculum, the journalism graduate students were asked to estimate the quantities for all these Top 40 phenomena and to incorporate some of these rates (or similar rates they found) into news stories that they wrote for the course. For illustrative purposes, we describe two examples of how using specific Top-40 items could enhance journalistic practice. We refer to Table 6 in these examples:

\begin{tabular}{|c|c|c|}
\hline Item \# & Quantity Description & Amount \\
\hline 11 & Percentage of U.S. Earnings earned by the top $1 \%$ of earners & $17 \%$ \\
\hline 12 & $\begin{array}{l}\text { Percentage of U.S. Federal individual income tax revenue that comes from the top } \\
1 \% \text { of the earners }\end{array}$ & $38.1 \%$ \\
\hline 20 & U.S. GNI as a percentage of world GNI & $22.5 \%$ \\
\hline 21 & U.S. Military spending as a percentage of world military spending & $34 \%$ \\
\hline 25 & $\begin{array}{l}2015 \text { Department of Defense budget as a percentage of total } 2015 \text { U.S. federal } \\
\text { budget (for discretionary defense funding only, excluding nondiscretionary } \\
\text { defense funding) }\end{array}$ & $13 \%$ \\
\hline 35 & $\begin{array}{l}\text { Percentage of the world's carbon dioxide emissions produced by the United } \\
\text { States }\end{array}$ & $16.3 \%$ \\
\hline
\end{tabular}

Reporting on U.S. Income Redistribution Policies. Two of the Top-40 items regard the degree to which the U.S. tax code is progressive, meaning the tax rate increases as income increases (see Table 6, numbers 11 and 12, which are from Appendix B of Ranney et al. 2016). These items note that, as of 2015, the top $1 \%$ of U.S. earners paid $38 \%$ of the income tax of all Americans, whereas they earned $17 \%$ of all U.S. earnings. Armed with such rates, people may still argue that either too little or too much tax is progressively required, but the deeper point is that too few people know these critical base rates when they engage in discussions about U.S. tax code appropriateness - which is a problem for a society hoping to be numerate. Articles covering this debate ought, we believe, incorporate such data to challenge readers' tacit estimates of what members of the top $1 \%$ of earners actually (a) earn and (b) pay in taxes.

Reporting on the U.S.'s International Role. Four other Top-40 items address several features of the U.S.'s global role regarding the two issues of climate change and military activity (see Table 6, numbers 20,21, 25, and 35, which are from Appendix B of Ranney et al. 2016). The first two items indicate that the U.S.which accounts for about $4 \%$ of Earth's population-accounts for $34 \%$ of global military spending and about $22.5 \%$ of the Earth's Gross National Income (GNI). A

\footnotetext{
${ }^{8}$ See also "More Numerate: Numbers \& Evidence for News Writers" http://morenumerate.org/publications.html (accessed Dec 16, 2016)
} 
third item shows that the U.S. spends around $13 \%$ of its federal budget on the Defense Department, although most nations devote much smaller portions for defense. A fourth item notes that U.S. produces $16.3 \%$ of Earth's $\mathrm{CO}_{2}$, which is almost four times what would be a "proportionate" allotment of emissions based on national population. Articles characterizing how the U.S. allocates its budget or how the U.S. negotiates climatic and military responsibilities with other nations can include such rates to surprise the many readers who come to such articles with an incoherent or under-informed perspective of how distinctive the U.S. military spending rates and climate-impact rates are relative to its portion of the global population.

\section{Conclusion and Reflection on Future Directions for This Work}

As shown in this article, providing accurate scientific explanations and even a very small set of key numbers can have a helpful educative impact on citizens - as well as journalists and journalism students. For reasons that are not well understood, the combination of (a) providing such quantitative and scientific information and (b) engaging participants in brief reflections around their positions on these elements, provides more than context to news stories: this combination also provides cognitive anchoring and an element of surprise that can lead to the transformation or revision of one's understanding of issues. The surprises elicited by such numerical and scientific information are what we believe generate the intervention's positive, corrective impacts. Given accurate data and explanations, the natural empiricist in all of us often responds accordingly and appropriately. Building on the work of Meyer and Paulos, we found that offering the benchmark rates and the causal theories stimulated the revision of preexisting tacit assumptions about particular social and environmental phenomena among most study participants.

As a practical matter, journalists often get such details right when they create longer "feature" stories. ${ }^{9}$ However, with the continued time-and-resource reductions reporters have suffered of late, the recommendations included in this article provide an economical set of guidelines for improving the transformative quality of journalistic reporting. Further, our guidelines are particularly useful for a generation of journalists that increasingly relies on secondary Web-based sources to produce news:

\footnotetext{
${ }^{9}$ Indeed, in newsrooms, these longer features were often described as "takeouts," which by their very name reflects how such reporting occurred "outside" the typical news production cycle.
} 
- When explaining what has occurred, provide numerical information to convey context and support sense-making, such as the rate and scope of a phenomenon.

- When explaining why an event has occurred, identify and summarize the core ideas of relevant scientific explanatory model(s).

Such numerical and explanatory context may be provided by using (a) rates of common social phenomena, and (b) scientifically verified causal explanations. To stimulate their own practical reasoning about numerical rates, journalists are encouraged to approach any core phenomenon in their reports by using the estimation strategies we have listed (e.g., seeking to disconfirm estimates, breaking a sought quantity into multiple quantities with better-known numeric values, using numbers to increase the explanatory clarity of a phenomenon, contrasting a quantity with the scope of a more aggregated quantity, and using the "Rule of 72 " heuristic to estimate the time it takes a geometrically increasing phenomenon to double). They should also take into account the variables that drive the rates they find, using their judgment about how to explain them. For example, a reporter citing the U.S.'s share of world military spending (34\%) may choose to briefly explain some of the primary contributing factors of that number, such as the costs of maintaining overseas bases, servicing an aging nuclear arsenal as a defense "umbrella" over various nations, and providing health care for military service members and their families.

In this era of journalism, in which fake news competes for attention with real news and both fact-checking exercises and scientific findings are frequently framed as questionable artifacts in a larger political battlefield, journalists may approach the tasks we recommend here with caution and concern. However, as we have demonstrated above, if journalists keep their focus on the rates and verified causal explanations surrounding the central phenomena addressed in their news reports, they will be performing a valuable public service that should, more often than not, advance public understanding. As an addition to the interventions we have recommended throughout this article, journalists should increase their familiarity with the kinds of procedures that scientists employ to reduce threats to validity and objectivity, such as replicable study designs and statistical tests that both quantify the magnitude of the results and ensure that the results are not due to chance.

In the future, the primary challenge for journalists in incorporating such information, given the time-pressed and resource-poor context of news production, is making such accurate benchmarks and concise descriptions of scientific models more easily accessible to them. As journalism teaches its practitioners, much critical numerical and scientific information is buried deep within the technical writing of the professions (the law, physical science, medicine, social science research, etc.). At the present time, there is too little incentive for the professionsand the societal elites they serve - to make such critical information easily accessible. Consequently, journalists remain one of the few professions in society 
dedicated to the process of extracting the necessary information for the benefit of public learning.

As we have discussed, recent trends in the news media business/production mean that journalists have less and less opportunity to serve as society's information watchdogs, archeologists, and sense-makers. Future research should continue to expand the methods and tools to support the shrinking number of journalists doing this hard work. Such support is needed not just for the so-called top-tier journalists - who gain easier access to societal elites because their stories confer these elites with their status and fame-but to the lower-level, low-paid reporters and bloggers who do most of the news gathering, reporting, editing, and imaging that is collectively consumed by media audiences each day. Future research should also examine the ways in which the rise of the use of academic, professional, and specialized language has negatively affected the free flow of informed democratic discourse in society, and should discuss ways to foster an ethic among the professions to convey their work in the plain language and the accurate numbers that will better serve to enlighten all citizens.

\section{Acknowledgments}

The authors thank journalist and journalism educator Tom Johnson and journalism school administrators Cynthia Gorney, Orville Schell, and Neil Henry for access to their journalism students during some of the studies described in this report. We also thank all the other researchers who worked on these studies, particularly Ed Munnich, Lee Nevo Lamprey, and Patricia Schank. Further, we are grateful to Leela Velautham, Ed Munnich, Nina Pak, Alyssa Kehlenbach, and members of the Reasoning Group of the University of California, Berkeley, for comments on an earlier version of this piece. Some of the work discussed was funded by the William and Flora Hewlett Foundation, the Carnegie Foundation, the Committee on Research at the University of California, Berkeley, and a bequest from the estate of Professor Barbara White. Conclusions or interpretations reflected in this article do not necessarily reflect the opinions or positions of these funders.

\section{References}

Ausubel, David. P., and Mohamed Youssef. 1963. "Role of Discriminability in Meaningful Parallel Learning." Journal of Educational Psychology 54 (6): 331336. https://doi.org/10.1037/h0042767.

Becker, Lee B., Tudor Vlad, and Holly Simpson. 2014. "2013 Annual Survey of Journalism Mass Communication Enrollments: Enrollments Decline for Third Consecutive Year." Journalism \& Mass Communication Educator 69 (4): 349365. 
Boykoff, Maxwell T., and Jules M. Boykoff. 2007. "Climate Change and Journalistic Norms: A Case-Study of U.S. Mass-Media Coverage.” Geoforum 38 (6): 11901204. https://doi.org/10.1016/j.geoforum.2007.01.008.

Clark, Dav, and Michael Andrew Ranney. 2010. "Known Knowns and Unknown Knowns: Multiple Memory Routes to Improved Numerical Estimation.” In Proceedings of the 9th International Conference of the Learning Sciences, 460467. Chicago, IL: International Society of the Learning Sciences.

Cohen, Sarah. 2001. Numbers in the Newsroom: Using Math and Statistics in the News. Columbia, MO: Investigative Reporters and Editors, Inc.

Cohn, Victor and Lewis Cope. 2012. News and Numbers: A Writer's Guide to Statistics. 3rd edition. West Sussex: Wiley Blackwell.

Curtin, Patricia A., and Scott R. Maier. 2001. "Numbers in the Newsroom: A Qualitative Examination of a Quantitative Challenge." Journalism and Mass Communication Quarterly 78 (4): 720-738. https://doi.org/10.1177/107769900107800407.

De Botton, Alain. 2014. The News: A User's Manual. New York, NY: Pantheon Books.

Fairhurst, Gail and Robert A. Sarr. 1996. The Art of Framing. San Francisco: JosseyBass.

Fischhoff, Baruch. 1993. "Risk Perception and Communication." Risk Analysis and Human Behavior, 1993: 3-32. https://doi.org/10.1146/annurev.pu.14.050193.001151.

Garcia de Osuna, Jennifer, Michael Ranney, and Janek Nelson. 2004. "Qualitative and Quantitative Effects of Surprise: (Mis)Estimates, Rationales, and Feedbackinduced Preference Changes While Considering Abortion.” In Proceedings of the Twenty-Sixth Annual Conference of the Cognitive Science Society, 422-427. Mahwah, NJ: Erlbaum.

Harrison, Steven. 2016. "Journalists, Numeracy and Cultural Capital.” Numeracy 9 (2): Article 3.

Hastie, Reid, and Bernadette Park. 1986. "The Relationship Between Memory and Judgment Depends on Whether the Judgment Task Is Memory-Based or OnLine." Psychological Review 93 (3): 258-268. https://doi.org/10.1037/0033295X.93.3.258.

Holyoak, Keith James, and Paul Thagard. 1996. Mental Leaps: Analogy in Creative Thought. Cambridge, MA: MIT Press.

Huff, Darrell. 1954. How to Lie with Statistics. New York, NY: Norton.

Iyengar, Shanto, and Donald R. Kinder. 2010. News That Matters: Television and American Opinion. Chicago, IL: University of Chicago Press. https://doi.org/10.7208/chicago/9780226388601.001.0001.

Just, Marion, Rosalind Levine, and Kathleen Regan. 2002. Investigative Journalism Despite the Odds: Watchdog Reporting Continues to Decline. Project for Excellence in Journalism. New York: Columbia University Graduate School of Journalism. Accessed October 29, 2016. 
http://www.journalism.org/2002/11/01/investigative-journalism-despite-theodds $/$.

Kahneman, Daniel, and Amos Tversky. 1984. "Choices, Values, and Frames." American Psychologist 39 (4): 341-350. https://doi.org/10.1037/0003066X.39.4.341.

Karabel, Jerome. 2015. "Police Killings Surpass the Worst Years of Lynching, Capital Punishment, and a Movement Responds." The Huffington Post. Accessed September 11, 2016. http://www.huffingtonpost.com/jeromekarabel/police-killings-lynchings-capital-punishment_b_8462778.html.

Klinenberg, Eric. 2005. "Convergence: News Production in a Digital Age." The Annals of the American Academy of Political and Social Science 597 (1): 48-64. https://doi.org/10.1177/0002716204270346.

Levitt, Steven D., and Stephen J. Dubner. 2005. Freakonomics. New York, NY: HarperCollins.

Matier, Phillip and Andrew Ross. 2004. 'Cops' Guns No Match for Gang-Bangers' AK-47s.” SFGATE, April 26.

Mauler, Edward. 2004. "Abortion Divides Camps." The Lantern, October 25, 2004. McCombs, Maxwell. 2005. "A Look at Agenda-Setting: Past, Present and Future." Journalism Studies 6 (4): 543-557. https://doi.org/10.1080/14616700500250438. — and Donald L. Shaw. 1972. "The Agenda-Setting Function of Mass Media." Public Opinion Quarterly 36 (2): 176-187. https://doi.org/10.1086/267990.

- 1993. "The Evolution of Agenda-Setting Research: Twenty-Five Years in the Marketplace of Ideas." Journal of Communication 43 (2): 58-67. https://doi.org/10.1111/j.1460-2466.1993.tb01262.x.

Meyer, Philip. 2002. Precision Journalism: A Reporter's Introduction to Social Science Methods. Lanham, MD: Rowman \& Littlefield Publishing Group. Munnich, Edward L., and Michael Andrew Ranney. Forthcoming. "Learning from Surprises: Harnessing Metacognition to Challenge and Reshape Our Belief Networks." Invited submission to a special issue.

—_, and Mandy L. N. Bachman. 2005. "The Longevities of Policy-shifts and Memories Due to Single Feedback Numbers." In Proceedings of the TwentySeventh Annual Conference of the Cognitive Science Society, 1553-1558. Mahwah, NJ: Erlbaum.

— Janek M. Nelson, Jennifer M. Garcia de Osuna, and Nolli B. Brazil. 2003. "Policy Shift Through Numerically-driven Inferencing: An EPIC Experiment about When Base Rates Matter." In Proceedings of the Twenty-Fifth Annual Conference of the Cognitive Science Society, 834-839. Mahwah, NJ: Erlbaum.

Paulos, John Allen. 2013. A Mathematician Reads the Newspaper. New York, NY: Basic Books.

Pew Research Center. 2012. "The State of the News Media 2012: An Annual Report on American Journalism." Accessed August 7, 2016. http://www.stateofthemedia.org/2012/newspapers-building-digital-revenuesproves-painfully-slow/newspapers-by-the-numbers/\#revenue. 
_. 2016. "State of the News Media 2016." Pew Research Center. Accessed August 20, 2016. http://www.journalism.org/2016/06/15/state-of-the-newsmedia-2016/.

Piaget, Jean. 1977. The Development of Thought: Equilibration of Cognitive Structures. Translated by A. Rosin. New York, NY: Viking.

Price, Vincent, David Tewksbury, and Elizabeth Powers. 1997. "Switching Trains of Thought the Impact of News Frames on Readers' Cognitive Responses." Communication Research 24 (5): 481-506. https://doi.org/10.1177/009365097024005002.

Quinn, Sara Dickenson. 2012. "New Poynter Eyetrack Research Reveals How People Read News on Tablets." The Poynter Institute. Accessed August 29, 2016. http://www.poynter.org/2012/new-poynter-eyetrack-research-reveals-howpeople-read-news-on-tablets/191875/.

Ranney, Michael Andrew, and Dav Clark. 2016. "Climate Change Conceptual Change: Scientific Information Can Transform Attitudes." Topics in Cognitive Science 8: 49-75. https://doi.org/10.1111/tops.12187.

— http://www.HowGlobalWarmingWorks.org.

— Edward L. Munnich, and Lee Nevo Lamprey. 2016. "Increased Wisdom from the Ashes of Ignorance and Surprise: Numerically-Driven Inferencing, Global Warming, and Other Exemplar Realms." In The Psychology of Learning and Motivation, ed. B. H. Ross, 129-182. New York, NY: Elsevier.

— Luke F. Rinne, Louise Yarnall, Edward Munnich, Luke Miratrix, and Patricia Schank. 2008. "Designing and Assessing Numeracy Training for Journalists: Toward Improving Quantitative Reasoning among Media Consumers." In Proceedings of the 8th International Conference for the Learning Sciences, 2-246 to 2-253. Chicago, IL: International Society of the Learning Sciences.

_- Franz Cheng, Jennifer Garcia de Osuna, and Janek Nelson. 2001. "Numerically Driven Inferencing: A New Paradigm for Examining Judgments, Decisions, and Policies Involving Base Rates." The annual meeting of the Society for Judgment and Decision Making. Orlando, FL.

Rinne, Luke F., Michael A. Ranney, and Nicholas H. Lurie. 2006. "Estimation as a Catalyst for Numeracy: Micro-Interventions That Increase the Use of Numerical Information in Decision-Making." In Proceedings of the 7th International Conference on Learning Sciences, 571-577. Chicago, IL: International Society of the Learning Sciences.

Scheufele, Dietram. 1999. "Framing as a Theory of Media Effects." Journal of Communication 49 (4): 103-122. https://doi.org/10.1111/j.14602466.1999.tb02784.x.

Scheufele, Bertram T., and Dietram A. Scheufele. 2010. "Of Spreading Activation, Applicability, and Schemas.” In Doing News Framing Analysis: Empirical and 
Theoretical Perspectives, eds. P. Kuypers and J. A. D'Angelo, 110-134. New York, NY: Routledge.

Silverman, Craig. 2016. "Here's How Fake Election News Outperformed Real Election News on Facebook." Accessed December 10, 2016. https://www.buzzfeed.com/craigsilverman/viral-fake-election-newsoutperformed-real-news-on-facebook?utm_term=.puqqKdqzg\#.fkyVmMVOB.

Timberg, Craig. 2016. 'Russian Propaganda Effort Helped Spread 'Fake News' During Election, Experts Say." Washington Post, November 24.

https://www.washingtonpost.com/business/economy/russian-propaganda-efforthelped-spread-fake-news-during-election-experts-say/2016/11/24/793903b68a40-4ca9-b712-716af66098fe_story.html?utm_term=.ced732a91ab8.

Wertheimer, Michael. 1945. Productive Thinking. Oxford: Harper.

Yarnall, Louise, J. Tom Johnson, Luke Rinne, and Michael Andrew Ranney. 2008. "How Post-Secondary Journalism Educators Teach Advanced Car Data Analysis Skills in the Digital Age." Journalism \& Mass Communication Educator 63 (2): 146-164. https://doi.org/10.1177/107769580806300204.

_ Michael Ranney, and J. Tom Johnson. 2005. "Quantitative And/or Narrative Information's Effects on Readers' Understandings and Perceptions of Events from News Reports." Menlo Park, CA: Content Guild talk at SRI International, April. 


\section{Appendix A. Articles Presented in Pilot Study}

\section{Abortion Article}

Source: Mauler 2004

After three debates, both presidential candidates have cleared the air and said where they stand on abortion, a key issue in this year's national election.

During the third debate, held Oct. 13 at Arizona State University, Bob Schieffer from CBS News served as moderator and asked both George W. Bush and John Kerry what their views are on abortion. Both debaters responded with opposite answers.

"I believe the ideal world is one in which every child is protected in law and welcomed to life," Bush said during the third debate. "I understand there's great differences on this issue of abortion, but I believe reasonable people can come together and put good law in place that will help reduce the number of abortions."

Kerry is Catholic and said he does not agree with Catholic ideology on the issue and in the process countered Bush's stance on abortion.

"I believe that I can't legislate or transfer to another American citizen by article of faith," Kerry said during the third debate. "I respect their views ... I am a Catholic, and I grew up learning how to respect those views, but I disagree with them, as many do."

Ohio Democrats and Republicans both have said the issue of whether a woman can legally terminate her pregnancy is important for this election.

\section{<<Point of inserting numerical information in Treatment article>>}

"In any national election, abortion becomes an issue," said Dan Trevas, spokesman for the Ohio Democratic Party. "In some segments of the population, it is a bigger issue than others. It is not necessarily immune to one party."

Deborah Burstion-Donbraye, director of Campaign American for the Ohio Republican Party, said that abortion should not be taken lightly and said abortion harms society.

"I can't think of a right that we granted that we have successfully taken away," Burstion-Donbraye said about the legalization of abortion in 1973. "When I talk about (abortion) politically, it is getting people to understand this element and to focus on how such a horrible situation it is."

The significance of how abortion will affect this election has increased with rumors that up to three judges could resign from the U.S. Supreme Court during the next four years.

The winning presidential candidate could replace those retired justices with individuals who have similar views on abortion, Trevas said. 
"For the issue of choice, the appointment of Supreme Court justices is important," he said. "Kerry announced that he would only appoint pro-choice justices."

Abortion became legal in all 50 states after the 1973 Roe v. Wade Supreme Court decision. The Supreme Court voted 7-2 to allow abortion on demand in the U.S., and antiabortion activists such as Denise Mackura, the executive director of the Ohio Right to Life, said the Supreme Court had no place in the abortion debate.

"When we are having this debate, where is the proper balance of rights?" she said. "The Supreme Court came along and cut that conversation short. I think that is why our country is still very troubled over this. The problem is that Roe v. Wade prohibits or stops us from making that decision. In reality, that is why we are still at war over this after 31 years."

While campaigning over the summer, Kerry said he believed that life began at conception but in the third debate Kerry cleared up his stance on abortion and said that abortion is a woman's choice.

"I believe that choice is a woman's choice," Kerry said. "It's between a woman, God and her doctor, and that's why I support that."

During the third debate, Bush said Kerry's views do not fit in with mainstream America and said Kerry takes his stance on abortion too far.

"Take, for example, the ban on partial-birth abortion," Bush said. "It's a brutal practice. People from both political parties came together in the halls of Congress and voted overwhelmingly to ban that practice. It made a lot of sense. My opponent, in that he's out of the mainstream, voted against the law."

Activists on both sides of the debate -- such as Makura and Denise Copeland, the executive director of the National Abortion and Reproductive Rights Action League Pro-Choice Ohio, both said that abortion affects other issues present in society today and the in the future.

"It really spills over to contraception," Copeland said. "I think the one thing about this election is that NARAL will be reaching out to young women. Collegeaged voters will have an impact on this election. I hope they will consider what the next 10 to 20 years of their lives will be like when they vote in November."

Makura said abortion affects women in a different way and spills over to issues other than contraception.

"In many ways the resort to abortion has allowed us to escape the realities of the kinds of problems that confront us in real life with difficult pregnancies," she said. "It is like we don't have to deal with the underlying problems of poverty or racism or the population issues or even abuse because she can always get an abortion. It allows us to escape those real issues because the abortion never solves the underlying problems. In a way, it has cheated women in our view of the real attention to things like pregnancy discrimination." 


\section{Police Homicide Article}

Source: Matier and Ross 2004

Ballistics experts are analyzing the AK-47 semiautomatic rifle used in the killing of San Francisco police Officer Isaac Espinoza to determine whether it was used in any of the other assault-weapon shootings that have surged across parts of San Francisco in the past six months, law enforcement sources say.

Investigators hope to match bullet casings from the weapon to other bullet casings found at the scenes of as many as a dozen other shootings involving AK$47 \mathrm{~s}$.

Terence Clark, the San Francisco group supervisor for the federal Bureau of Alcohol, Tobacco, Firearms and Explosives, declined to discuss details of the Espinoza murder investigation, but said: "There have been a number of shootings in that area with that type of weapon."

In fact, according to one police source, AK-47s have emerged recently as "the gun of choice" among San Francisco's gang-bangers.

And it's sending a sobering chill throughout the Police Department. Some cops, who are armed only with .40-caliber Beretta handguns, say they feel like walking targets.

"I was on patrol out at Sunnydale the night of Espinoza's funeral," said one veteran officer. "The bangers were on the corners shouting out, 'I got an AK-47 for you.

"What do you think the message was?" the cop asked.

\section{$<<$ Point of inserting numerical information in Treatment article $>>$}

In addition to beefing up patrols, the cops -- along with the district attorney's office, ATF and Justice Department -- are quietly preparing to set up a special task force to crack down on 100 or so of the most dangerous parolees. Those are the ones who have been identified not only as having serious criminal histories, but also a propensity for carrying weapons.

"Our effort will be to try to get some of these guns off the street," said Chief Assistant District Attorney Russ Giuntini. "It will involve enforcement, as well as an increased call in the bail schedule whenever a gun is used."

According to the ATF's Clark, the feds and local police have already made strides in getting gun-toting gang members behind bars with a program called Trigger Lock, in which ex-felons caught carrying a firearm can be prosecuted under a federal law that provides for prison sentences twice as long as under state law.

Last year alone, 31 people in the Bay Area -- mostly San Francisco gang members -- were prosecuted under the law, with many sent to out-of-state penitentiaries. Another 100 cases are winding their way through the justice system.

But while two of San Francisco's most notorious gangs -- Big Block and 
Westmob -- have been hit hard in the past couple of years, Clark says other thugs and gang-bangers have stepped up to their take their place in the Western Addition, Hunters Point and Sunnydale housing projects.

"The Police Department is encountering these weapons first-hand," Clark said, "and they can run into them anytime -- as, unfortunately, Officer Espinoza did." 